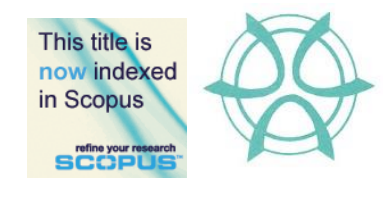

PLANNING MALAYSIA:

Journal of the Malaysian Institute of Planners

VOLUME 16 ISSUE 1 (2018), Page 265 - 280

\title{
IDENTITY, TRADITION AND THE CITY: DICHOTOMIES AND REALITIES OF CREATING AN URBAN LANGUAGE OF THE MALAY PALACE
}

\author{
Tengku Anis Qarihah Raja Abdul Kadir ${ }^{1}$, Puteri Shireen Jahn Kassim² \& \\ Nurul Syala Abdul Latip ${ }^{3}$ \\ ${ }^{1,2}$ Kulliyah of Architecture and Environmental Design, \\ INTERNATIONAL ISLAMIC UNIVERSITY MALAYSIA, \\ ${ }^{3}$ Faculty of Engineering and Built Environment, \\ UNIVERSITI SAINS ISLAM MALAYSIA
}

\begin{abstract}
This paper highlights a case study, its critical issues and the processes encountered in the evolution and development of its urbanised grammar. In deriving a localised language in which traditional forms are fused and transmuted into masonry architecture, the case study of the "Istana Negara" Palace is a case in point. The issues triggered within the design process, including how to represent a universal Malaysian identity reflecting Malay Asian character with Islamic vocabulary are explored. The difficulties and realities of transmuting and integrating such vocabulary to express and configure public masonry buildings are discussed. As an icon for the city, the palace must reconcile its scale with a clear localised vocabulary to fulfil the symbolic nature of the design. The conflicts and dichotomies encountered include three aspects: 1) The dome vs pitch form as an icon for the city (from afar) and the need for a strong roof silhouette 2) the local grammar and language including the pedestal and architrave vocabulary and elements 3 ) the difficulty of proportionate form. The research points to the necessity and urgency of developing a set of compositional rules and elements of the language of Malay urban architectural identity derived from the essences of tradition and regional form.
\end{abstract}

Keyword: Malay architecture, Istana Negara, identity, urban, tradition 
Tengku Anis Qarihah Raja Abdul Kadir, Puteri Shireen Jahn Kassim \& Nurul Syala Abdul Latip

Identity, Tradition and The City: Dichotomies and Realities of Creating an Urban Language of the Malay Palace

\section{INTRODUCTION}

Malay architecture and identity are disappearing in cities, as it is a form of traditional language and construction which predominantly arises from timber construction, detail and craftsmanship. Modern cities in Asia including Malaysia are predominantly are using concrete, steel and glass, whereby, its legacy of timber architecture is often no longer relevant in many urban sites. This scenario is strongly related to the urbanisation process faced by Asian cities (Kamarul Syahril Kamal, Lilawati Abdul Wahab, \& Asmalia Che Ahmad, 2004). In the past, the palace not only represents both the ruler's domain, but it is a node and administrative building for the people of the Malay region and its districts (Sherif, 2015). It is also the highest expression of the aesthetics of Malay identity. The rich variations of the Malay identity are a representation of Malay architecture, which is primarily houses, mosques and palaces (E. Hosseini, 2012). The palace is one of the examples, clear rules of space and order, based on a generic archetypical form - which based on the notion of the 'classical' in Malay literature and nationalist discourse (Shireen Jahn Kassim, 2017).

Hence it is not surprising that, in his critique of the monuments of Putrajaya, King (2007) observes that “...there is nothing identifiably Malay in the styling and its antecedents. There is no trace of the (Malay) Southeast Asian Great Mosque tradition with its tiered pyramidal roof forms, open walls and preoccupation with air movement". King represents an external observer of a new modern city and master plan in Malaysia which is at the heart of the Malay world but with no discernible, dominant, recognisable identity and language characteristic in a South East Asian tradition - particularly in this large master development. Historically, the core of Malay settlements and as part of its manifestation of tropical cities of the past, the Malay palace is as described by Yuan (1997), “... the heightened refinement of Malay cultural form, traditions and language and the 'urban' and monumental version of the Malay vernacular house, being the first building built before the settlement grows."

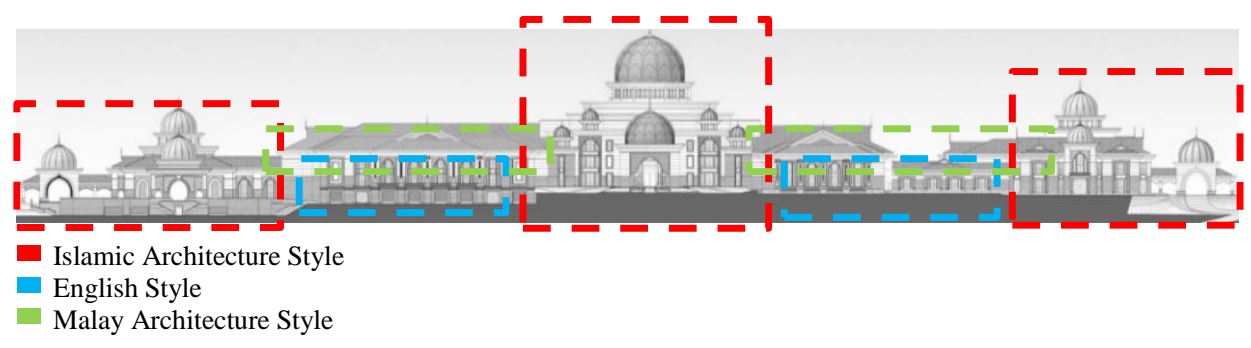

Figure 1: Front elevation of Istana Negara, Kuala Lumpur Sources: Kumpulan Senireka, 2017. Dotted line by authors 
PLANNING MALAYSIA

Journal of the Malaysia Institute of Planners (2018)

The difficulty is in defining universal rules from the complexity and variation neighbouring countries, through trades, origins of the owner or Malay colonial and local influences the character of the different states (Moser, 2012). The research first looks at the problems encountered in an actual design process and scenario of translating identity in large and complex modern scale of a project with masonry elements. Figure 1 showed the ultimate hybrid form of the language, styling of columns, roof forms, decorations of facades and lifted structure of the Malay palace, for example, Istana Negara. The paper describes difficulties were found based on frontage elements of vocabulary stylistic analysis. The difficulties arise among other essential elements of architectural language such as (i) roof form, (ii) façade; windows, doors, walls and architraves, (iii) columns; bracket and pedestal, (iv) raised floor, (v) ornamentations and (vi) balustrade and railings.

\section{CASE STUDY DESCRIPTION}

Based on interviews with the architect and group of designers, the following is a compilation of their intentions, which led to their process and their particular ideas and design brief. There is definite Malay intention in the essential internal planning of the 'istana' as there was a high reference to the traditional Malay houses of the península. Analysis conducted from a random comparison layout of the Istana Negara and traditional Malay houses where the author found that Istana Negara layout is closely similar to the traditional layout. The Istana Negara layout has three different entrances which separating three main building functions, which each of the entrances marked by the existence of the domes.

\section{Space Layout and Planning}

The layout plan of the Istana Negara initiated by the significance of tiang seri in a traditional Malay house. 'Tiang seri' is the first column to be built on site. The design of the Istana has an axial and strong symmetrical form which similarly to Istana Seri Menanti Layout. Figure 2 shows the essential hierarchy and axial form of Istana Negara. 'Rumah ibu' in this context is referred to the main lobby. The main lobby is assumed to have a 'tiang seri' which positioned in the centre of 'rumah ibu' and capped by a central dome which house the Balai Rong Seri. As a summary, 'Tiang seri' is symbolised by the grand dome at the centre while 'rumah ibu' is the main lobby. On the Hulu side, Royal Wing exists as an isolated unit for special occasions, such as the arrival of foreign ambassadors. Abstract application of the spatial organisation of Istana Negara much related to traditional Malay house - Hulu side contains private quarters for 'tuan rumah'. The adaptation of the Malay house might have similarity with the Royal Wing entrance. 'Tuan rumah' is referred to Yang Di-Pertuan Agong, the official residence of our Majesty. Women visitors in the abstract adaptation of Istana Negara referred to foreign ambassadors. Foreign ambassadors enter the Royal 
Tengku Anis Qarihah Raja Abdul Kadir, Puteri Shireen Jahn Kassim \& Nurul Syala Abdul Latip

Identity, Tradition and The City: Dichotomies and Realities of Creating an Urban Language of the Malay Palace

Wing to sleep over in Istana Negara. While East Wing on hilir side become the normal entrance for the public, neither VIPs nor Ministers. The spaces on this side accommodated for occasions, such as Tea Party, become public affairs with other guests. Adapting to the concept of 'hilir' in traditional Malay houses - it is spatially reflecting the spaces of traditional houses for "anak bujang" or bachelors and guests at 'pangkal serambi' or veranda.

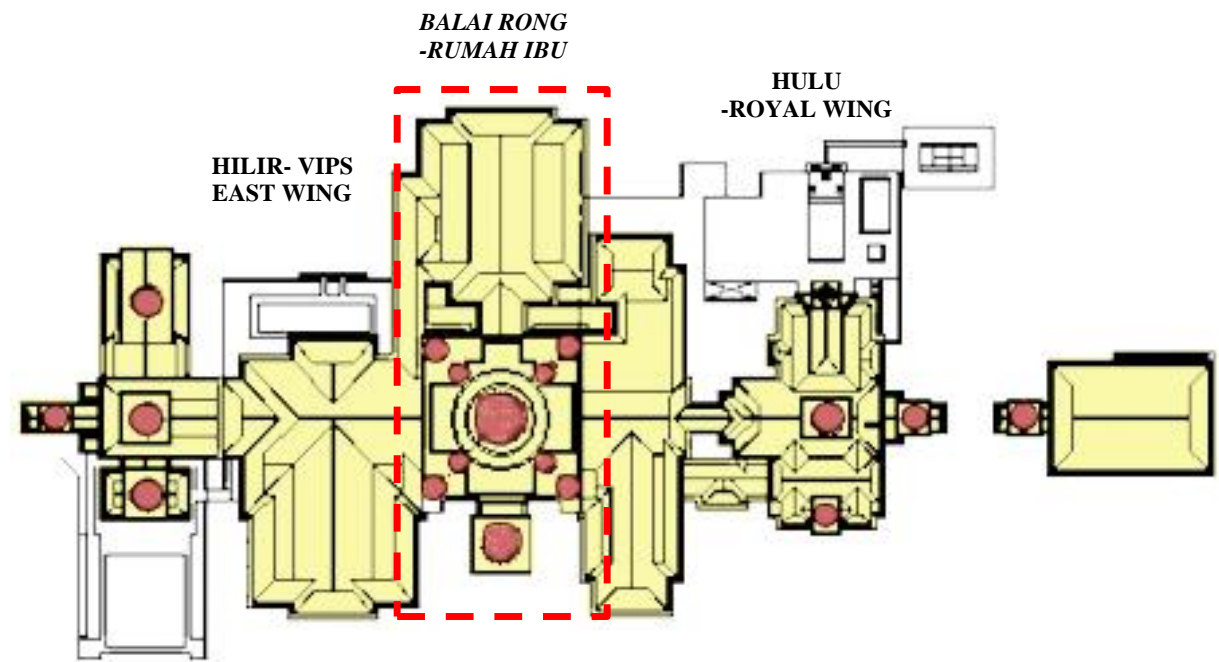

Figure 2: Shows the essential hierarchy and axial form of Istana Negara Sources: Kumpulan Senireka, 2017. Dotted line by authors

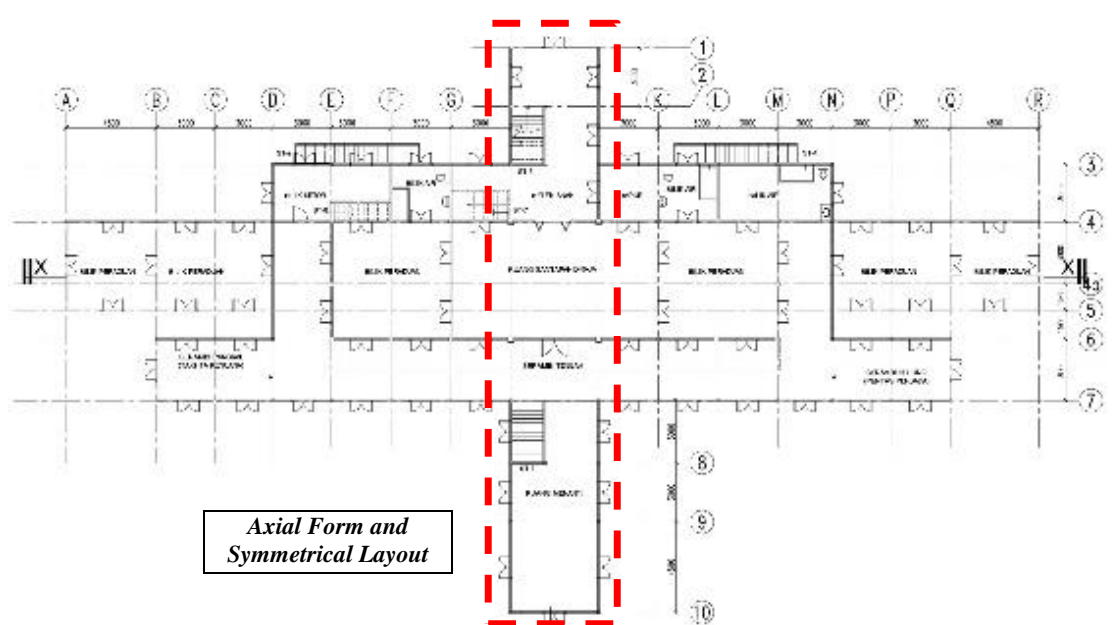

Figure 3: An axial form and strong symmetrical layout of Istana Seri Menanti Sources: Kumpulan Senireka, 2017. Dotted line by authors 
The grand entrance - paralleled to Royal Banquet Hall is the Prime Minister and other Ministers as well as VIP guests entrance. It has a reception lounge called the "Bilik Mengadap" for receiving audiences by His Majesty, where traditionally referring to the visitor's especially male guests are to be greeted and entertained at 'hujung serambi' and 'rumah ibu', so-called mother of the house. The traditional Malay houses layout planning dictate the Istana Negara layout to follow the social mores of the Malays, such as the provision of a private space for the womenfolk and a public space for the entertaining of Malay guests. Social segregation and the observance of the court behaviour in respect to hierarchy dictated the spatial organisation. The apparent difference found in the traditional Malay house and Istana Negara are the physical barriers. Traditional Malay houses are known for its congenial aspects - openness, the absence of partitions or solid ceiling-height walls separating the different areas. The houses divided into areas, rather than rooms for various social and household activities, while in Istana Negara, the establishment of barriers is the public and private domain which marked the territories for royalty and commoners. The elevation reflects a combination of 'bumbung panjang', and Islamic vocabulary in 'Classical' proportion also contradict with the norm of traditional Malay style. Comparing Figure 4, 5 and 6; it can be argued that the Istana Negara be a fusion of the axial typology and dual- symmetry typology of the Malay traditional palace form (Tengku Anis, 2017). The Istana Negara also reflect the 'bumbung panjang' form as in figure 5 while at the same time having an axial massing (a layout with an axis or strong vertical or horizontal line at the centre of a massing) as in Figure 6.

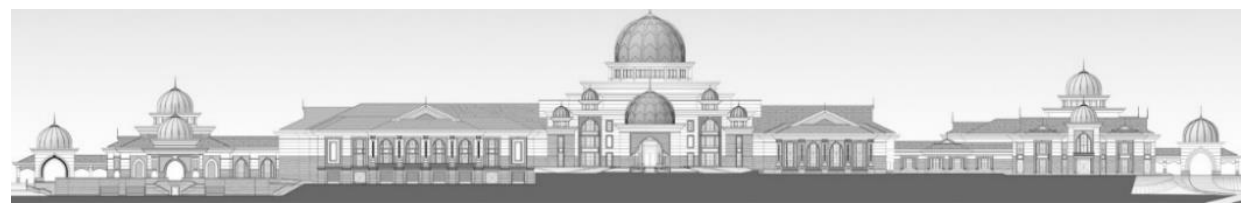

Figure 4: Istana Negara front elevation Source: Kumpulan Senireka Sdn. Bhd., 2017

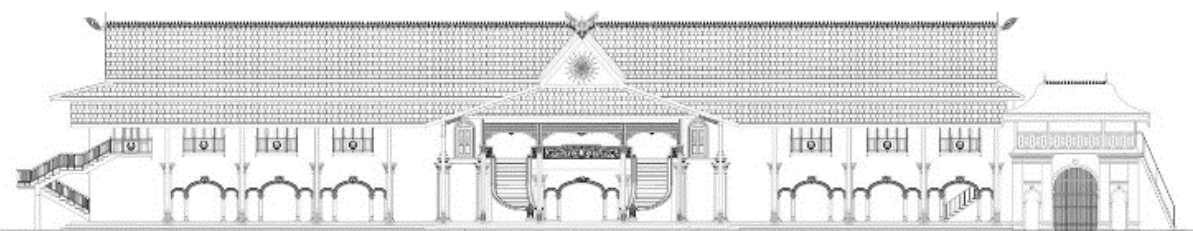

Figure 5: The Royal Audience Hall, Kedah - Elevation showing syncretism of Colonial and Malay form dominating the overall expression Source: IIUM KAED Heritage Center, 2017 


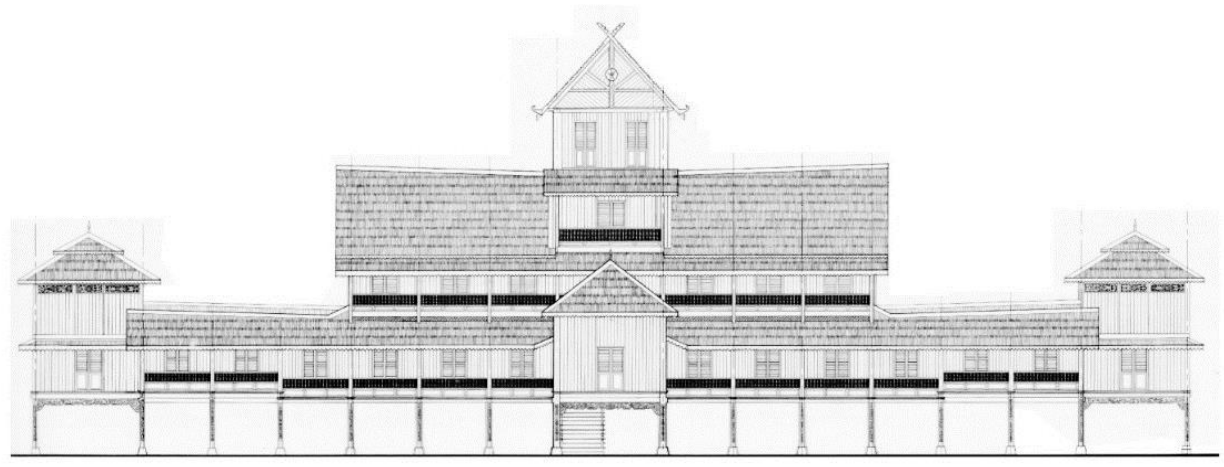

Figure 6: The Istana Seri Menanti, front elevation Source: KALAM, UTM, 2017

\section{Elevations and Façade Treatments}

There is an intuitive system of proportion used as the basis of elevation design of the Istana Negara as shown in Figure 7, which classical orders, repetition and hierarchy expressed. The proportions of the dome, roof, door, pillars, windows, arches, and the row of upper windows governed by simple division of an underlying grid. The walls form a cuboid, while the height of the dome corresponds to the traditional roof and height of the pillars. Designs for Istana Negara facade based on the rectangular block which features a central section, the grand entrance at Royal Banquet Hall, balanced on either side by wings of almost similar dimension and appearance. It is further enhanced by an array of the 'limas' roof, row of pointed arch and rectangular windows, pillars and pilasters, as well as various sizes of domes.

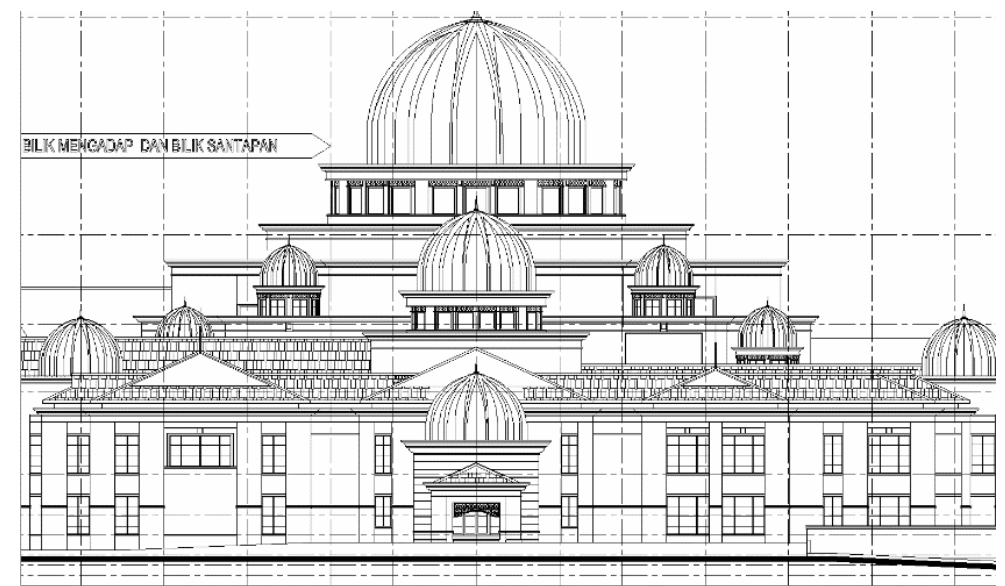

Figure 7: Symmetry adds balance and rhythm in Istana Negara façade. The massive dome surrounded with semi-domes. The domes create a form that reflect hierarchy. Source: Kumpulan Senireka Sdn. Bhd, 2017 
PLANNING MALAYSIA

Journal of the Malaysia Institute of Planners (2018)

Based on an interview conducted with its principal architect Ar. Nik Arshad, there was not only an intention to express Malay identity alone but also to uphold Islamic identity as this was requested officially by the government. To meet such national objectives and agenda, the dome was utilised as a device for symbolic purposes. Its centrality creates the verticality of the central space and makes it essential. A new system of space was created by the hierarchy of the central dome and the semi-domes. The design of the domes is based on the plan that shows the 14-ribs, symbolising the number of states in Malaysia. These dichotomies are related to the formality needed and in this case, these are resolved through the infusing Classical, Neo-Classical and Palladian language of architecture. Figure 8 shows how; 1) the triangular pediment was fused with Malay roof language (to adorn the roofscape), 2) to embellish the frontage the use of Classical 'orders' was slightly mutated but based on the tripartite system of the base, column, and capital.

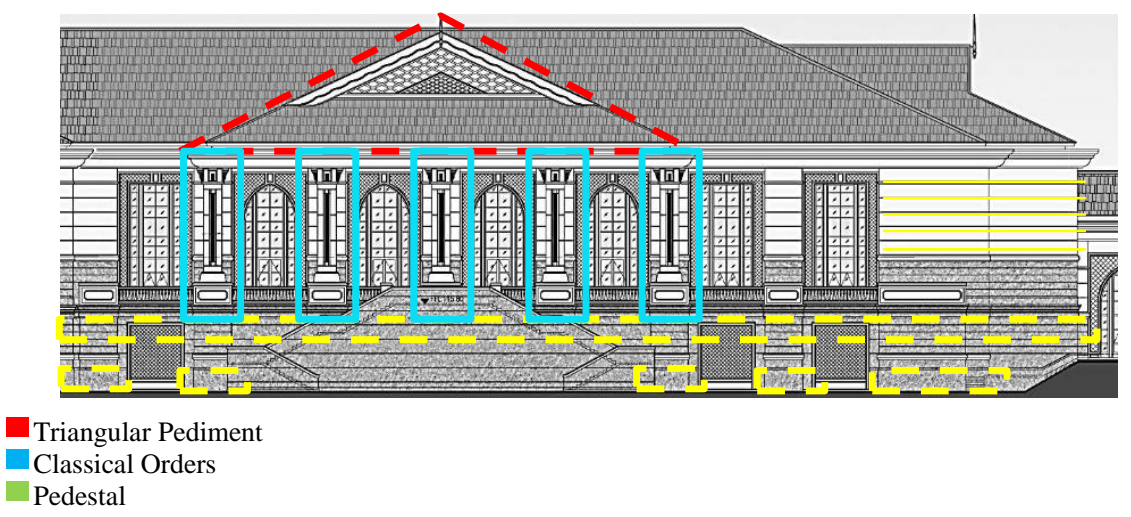

Figure 8: Infusion of Classical, and Palladian language of architecture of Istana Negara

Sources: Kumpulan Senireka Sdn. Bhd, 2017. Dotted lines by authors

\section{FINDINGS AND ARGUMENT}

The Istana Negara - dichotomy in design process

\section{Roof Forms}

While the typical expectation is to surmount the masonry body with an iconic Malay pitch roof, there were essential dichotomies in a symmetrical domed structure exposed in the middle due to the scale and size of the Istana Negara. As described by Sherif (2015), '...The systems of proportions governing the elevation of this building and the dimensions of the building elements are all governed by simple division of the basic grid' which can be seen in Figure 11 From an aerial viewpoint as per Figure 9, the 'bumbung limas' or 'bumbung 
Tengku Anis Qarihah Raja Abdul Kadir, Puteri Shireen Jahn Kassim \& Nurul Syala Abdul Latip

Identity, Tradition and The City: Dichotomies and Realities of Creating an Urban Language of the Malay Palace

panjang' dominates the roof surface area, however when viewed from the ground and afar, the Malay 'bumbung limas' appear to be subdued and less dominant compared to the occasional domes that mark the entrance area of the palace. Conventionally, Figure 10 indicates that the domes are relatively higher than Malay traditional-style roofs. Hence, the hierarchy of massing as expressed through the Istana Negara form seem to be expressed by variations in the dome levels rather than the traditional Malay roof.

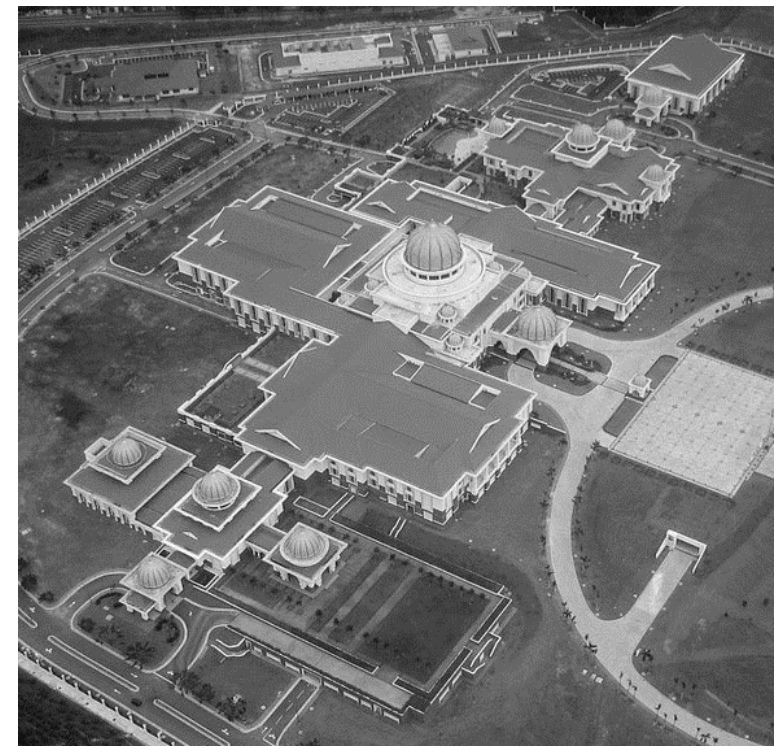

Figure 9: From aerial viewpoints of Istana Negara, the 'bumbung limas' or 'bumbung panjang' are dominated more than $90 \%$ of the roof surfaces. Sources: http://www.panoramio.com/photo/74835458, 2017

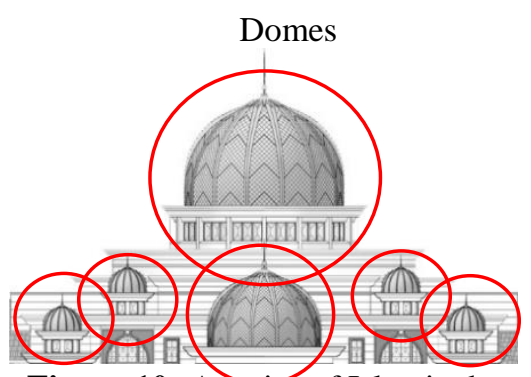

Figure 10: A series of Islamic domes was used to express the symbolic nature of the roof for Istana Negara.

Sources: Kumpulan Senireka Sdn. Bhd, 2017. Circled by authors

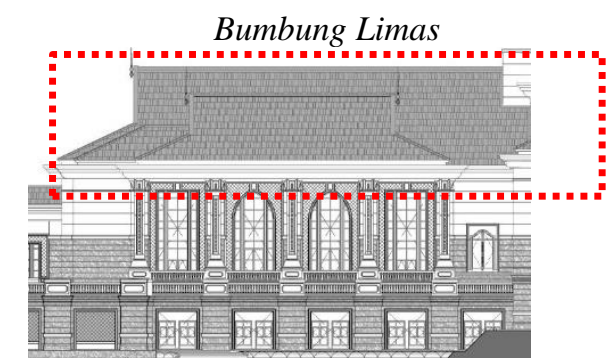

Figure 11: The Limas roof surfaces in Istana Negara are using 'Bumbung Limas' but still appear subdued.

Sources: Kumpulan Senireka Sdn. Bhd, 2017. Ddotted lines by authors 
PLANNING MALAYSIA

Journal of the Malaysia Institute of Planners (2018)

Gable - end /'Tebar layar', Facia Board 'Papan manis' and 'Tunjuk Langit' are the attempts made by the architects to enhanced the Malay Architecture Features. Figure 12 shows the 'Tebar layar', Facia Board 'Papan manis' and 'Tunjuk Langit' in Istana Negara which the author's find identical features in Baitul Rahmah, Perak in Figure 13.

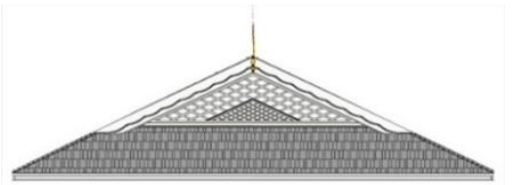

Figure 12: Gable end/ 'Tebar layar', facia board and 'Tunjuk Langit' Sources: Kumpulan Senireka Sdn. Bhd, 2017, Circled by authors

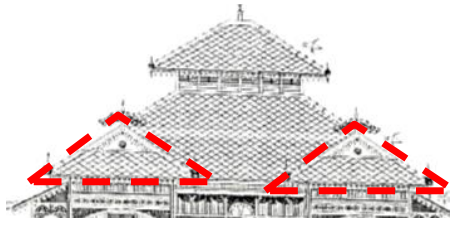

Figure 13: The front façade of Baitu Rahmah that shows the gable end roof. Source: IIUM KAED Heritage Center, 2017. Dotted by authors

\section{Windows and Doors}

The windows and doors appear in two shapes: one comprised rectangular windows with two different grille styles and the other high-length pointed arch windows with ornate 'Glass Fibre Reinforced Concrete' (GFRC) frames. Figure 14 shows the window and door designs in Istana Negara were inspired by European styles where keystone was placed at the middle, while Figure 15 shows the other types with the pointed arches recalling Islamic identity.

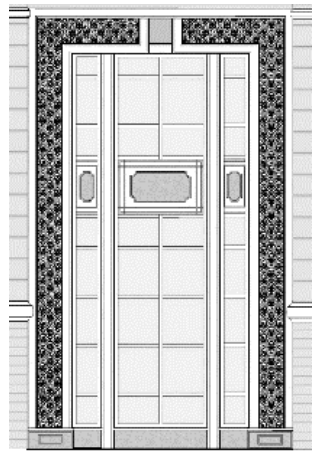

Figure 14: European styles of door and window where keystone

Sources: Kumpulan Senireka Sdn. Bhd, 2017

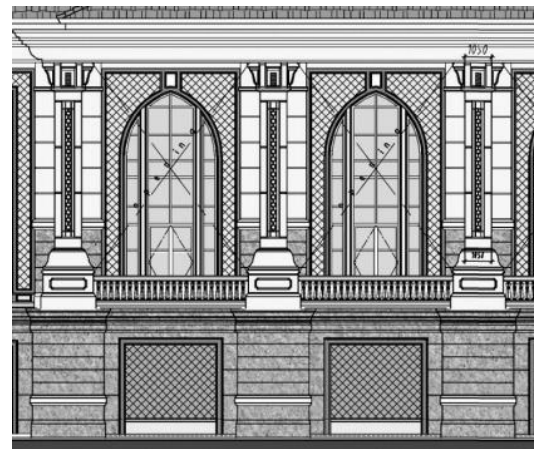

Figure 15: Pointed arches recalling Islamic identity of door and window

Source: IIUM KAED Heritage Center, 2017

\section{Walls and Architraves}

As one of the most challenging elements as there is no immediate precedent in Malay Architecture of the form, the architrave and pedestal designs referred to simple classical forms and motifs. These are particularly crucial as these elements help the façade design look less 'empty' as an attempt by architects for Istana 
Tengku Anis Qarihah Raja Abdul Kadir, Puteri Shireen Jahn Kassim \& Nurul Syala Abdul Latip

Identity, Tradition and The City: Dichotomies and Realities of Creating an Urban Language of the Malay Palace

Negara as Figure 16. Though many have criticised the Arab-eclectic of the Istana, yet evidently, there is an essential difficulty in any direct translation, transposition, and transmutation of Malay-timber based construction with materials as these needed a rescaled composition.

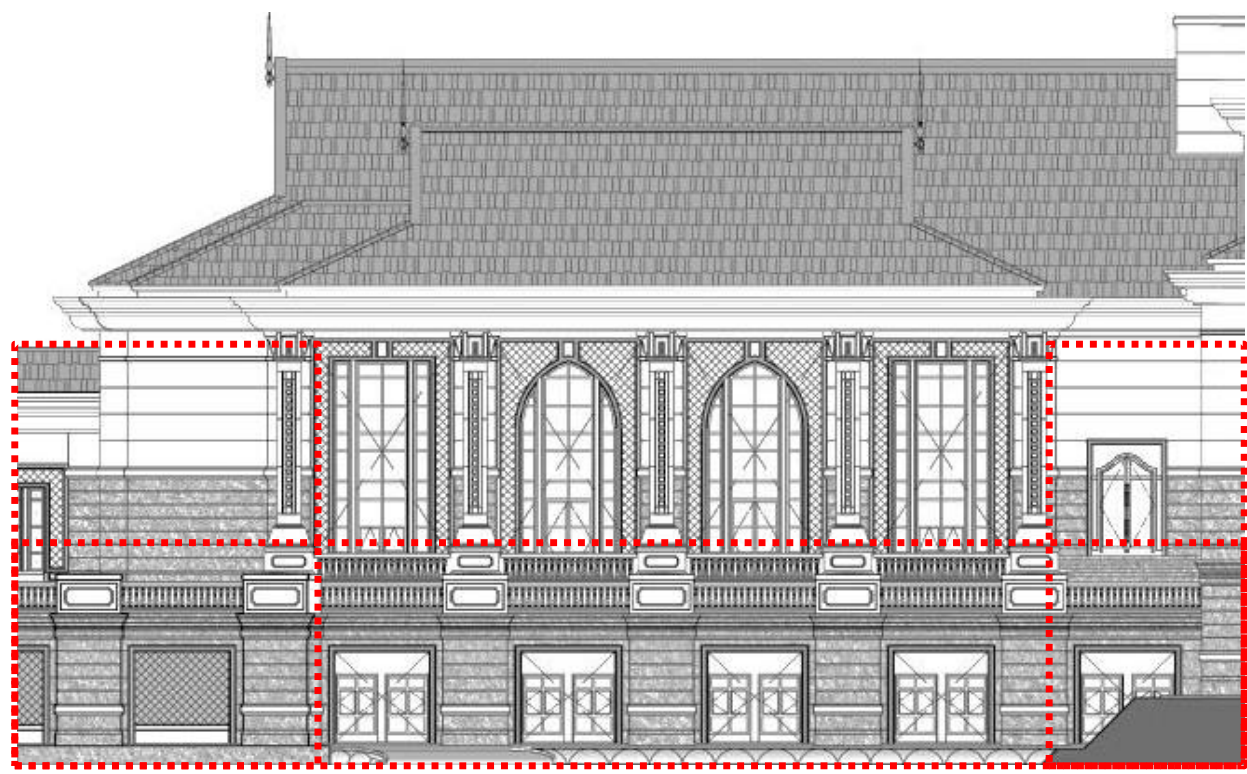

Figure 16: Architraves and façade pedestals

Sources: Kumpulan Senireka Sdn. Bhd, 2017. Dotted lines by authors

\section{Columns}

The character of Malay columns has been said as thin and slender (Shireen Jahn Kassim, 2017). The Malay character observed in traditional column styles can be typically distinguished by unadorned capitals and bases, unfluted columns, plain entablature, resting on a square plinth but with ornate brackets. Here the cornice is composed by an ovolo. Table 1 shows the ovolo mouldings are modularised look-alike 'sesiku' or bracket elements. 
PLANNING MALAYSIA

Journal of the Malaysia Institute of Planners (2018)

Table 1: Comparisons of sesiku (Bracket)

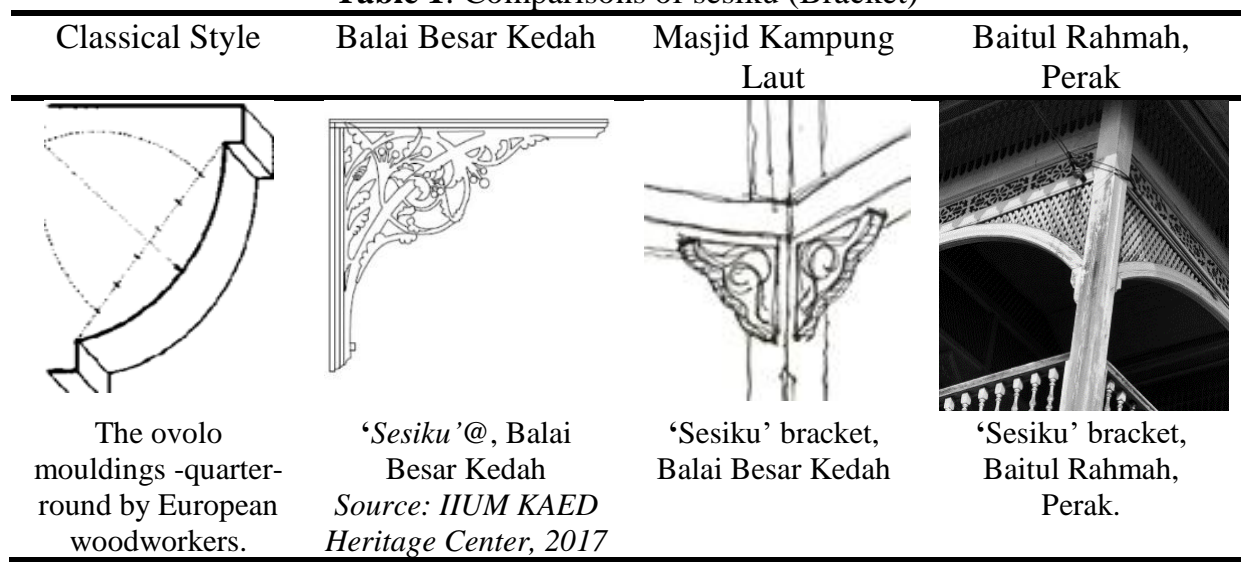

Table 2: Comparisons of columns

\begin{tabular}{cccc}
$\begin{array}{c}\text { Classical Column } \\
\left(8^{\text {th}} \text { - }{ }^{\text {th }} \text { B.C }\right)\end{array}$ & $\begin{array}{c}\text { Column, Istana } \\
\text { Jahar, Kota Bharu } \\
(1855)\end{array}$ & $\begin{array}{c}\text { Column, Istana } \\
\text { Negara, Kuala } \\
\text { Lumpur }\end{array}$ & $\begin{array}{c}\text { Column, Istana Baitul } \\
\text { Rahmah, Perak (1911) }\end{array}$ \\
\hline
\end{tabular}

A distinctly organised and compositional system was cultivated. There is no immediate Malay-based vocabulary for masonry elements like pedestals, yet local vocabulary reflecting Malay-Classical form and functions is found in the 'lapik tiang' in 1800's era at Istana Jahar, Kota Bharu and Baitul Rahmah, Perak. Table 2 shows a comparison of the different columns and identical elements that syncretise the old and new tradition by mutating a variation of the column in Istana Negara. Figure 17 and 18 reflects the eventual shape of the Istana Negara column which is a trapezoidal form of pedestal found in many palaces including Istana Seri Menanti, Negeri Sembilan. 
Tengku Anis Qarihah Raja Abdul Kadir, Puteri Shireen Jahn Kassim \& Nurul Syala Abdul Latip

Identity, Tradition and The City: Dichotomies and Realities of Creating an Urban Language of the Malay Palace

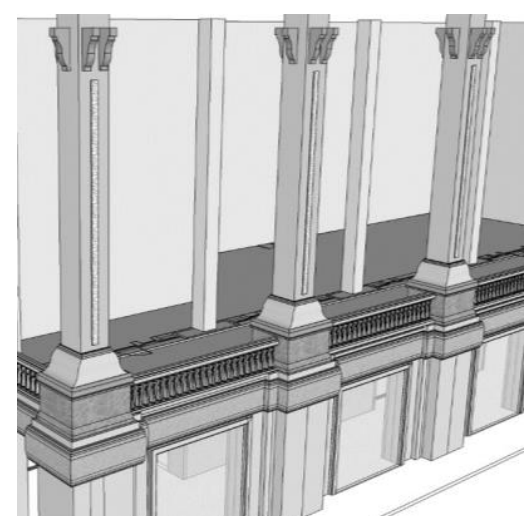

Figure 17: Columns and pedestals Istana Negara

Sources: Kumpulan Senireka Sdn. Bhd, 2017

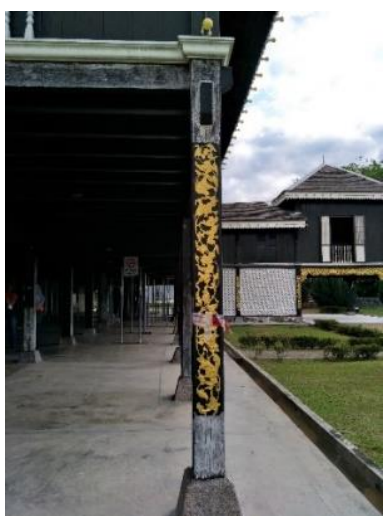

Figure 18: Columns and pedestals At Istana Seri Menanti, Negeri Sembilan

\section{Raised Floor and 'Lapik Tiang}

The characteristic form of Malay hybrid architecture comprises two levels, rests on series of square columns - composed of ovolo mouldings and high square bases. The upper levels are wide-open verandas, giving an impression of a basic concept of raised floor in traditional Malay houses. In the past, pillars had no longer buried in the ground like in the existing original Malay houses (Nasir, 1997). Figure 19 and 20 shows that the concrete bases are higher and the pillars are slender.

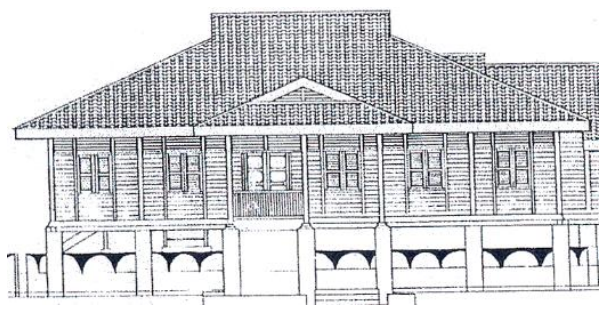

Figure 19: Most of Malay houses with pedestal called 'lapik tiang' (base of the post) or 'alam tiang'. Source: KALAM, UTM, 2017

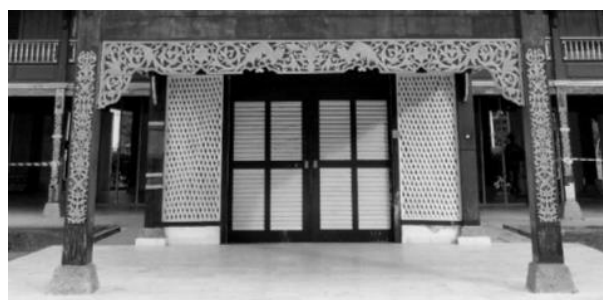

Figure 20: Most of Malay houses with pedestal called 'lapik tiang' (base of the post) or 'alam tiang.'

\section{Ornamentations}

A constant issue during the design process is which traditional motif can be universally accepted as a national symbol and language. Eventually the architects decided to use the 'Bunga Raya' motif which was abstracted into five petal form and universally applied as window frames and transoms. Figure 21 and 22 of the Bunga Raya motif was repeated into transoms as an emblem in the window and door panels which the input of experienced Malay craftsmen. In Istana Negara, 
PLANNING MALAYSIA

Journal of the Malaysia Institute of Planners (2018)

natural elements like hibiscus are used as a motif on the G.F.R.C grille design. There are many varieties of hibiscus, but the five-petalled hibiscus Rosa Sinensis as per Figure 23 and 24 was chosen by Tuanku Abdul Rahman in 1960 as used the national flower of Malaysia.

The terms 'Bunga' in Malay means flower, while 'Raya' means grand. In an attempt to base national unity, the hibiscus motif was used throughout the embelishments of the G.R.C grilles. Auguste Perret, who attempted to create a localised yet modern classical language using reinforced concrete in Perret's Rue D Apartment in Paris, France. Figure 25 shows how interestingly Perret's design treatments on wall while figure 26 indicates the edges of columns with decorative finials which similar to the buah buton of Malay Asian timber based tradition.

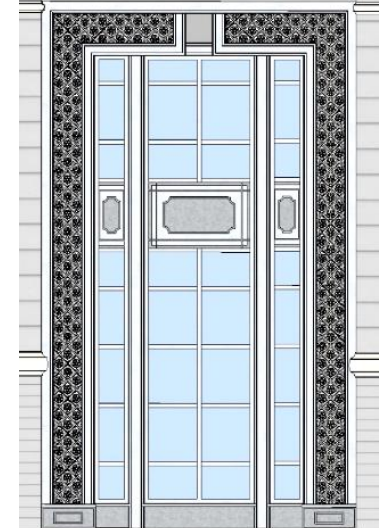

Figure 21: Window and door decorated with GFRC of hibiscus patterns.

Sources: Kumpulan Senireka Sdn. Bhd, 2017

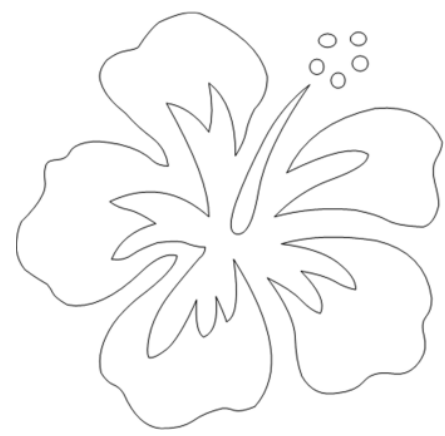

Figure 24: The hibiscus Rosa Sinensis is the national flower of Malaysia Sources: Kumpulan Senireka Sdn. Bhd, 2017

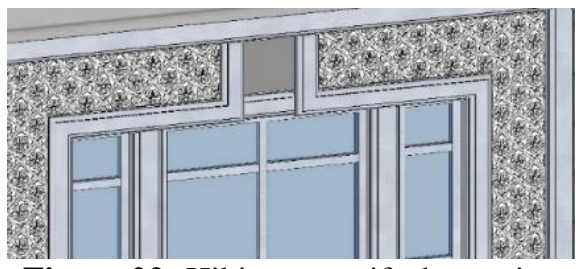

Figure 22: Hibiscus motifs decorating window frames and transom

Sources: Kumpulan Senireka Sdn. Bhd, 2017

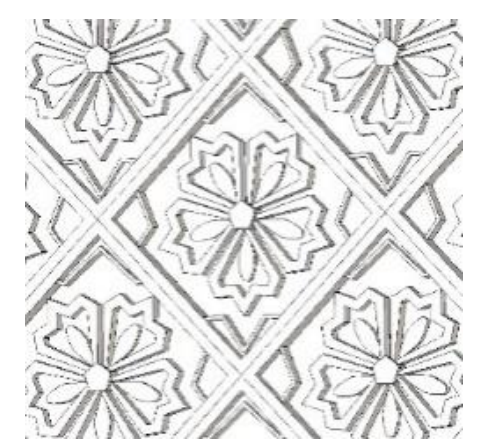

Figure 24: A motif simplification of hibiscus turns to GFRC

Sources: Kumpulan Senireka Sdn. Bhd, 2017 
Tengku Anis Qarihah Raja Abdul Kadir, Puteri Shireen Jahn Kassim \& Nurul Syala Abdul Latip

Identity, Tradition and The City: Dichotomies and Realities of Creating an Urban Language of the Malay Palace

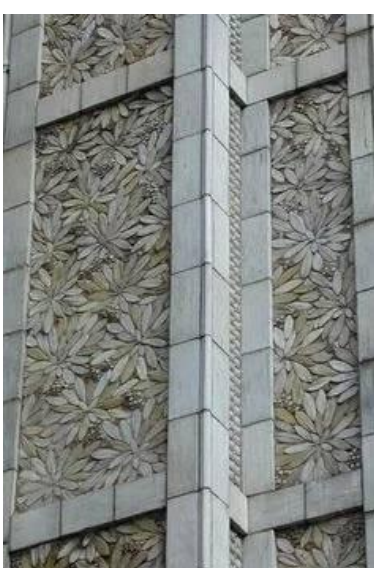

Figure 25: Perret's Rue D Apartment France, flower motifs used to decorate empty surfaces of concrete walls

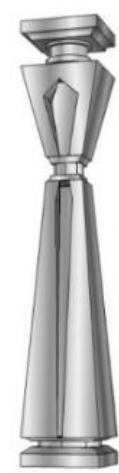

Figure 27: Conceptual modelling by the architect of the balustrade Sources: Kumpulan Senireka Sdn. Bhd, 2017

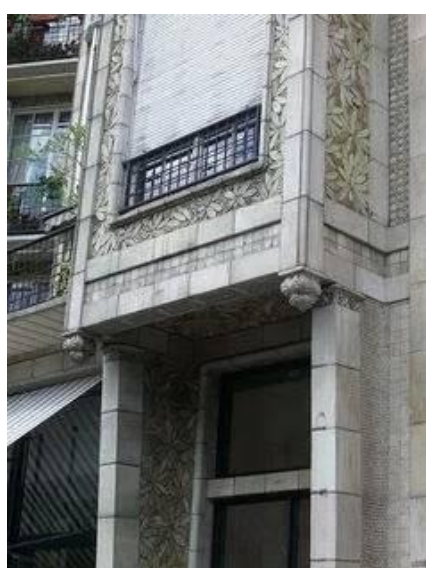

Figure 26: The decorative finials which similar to the buah buton Malay Asian timber based tradition.

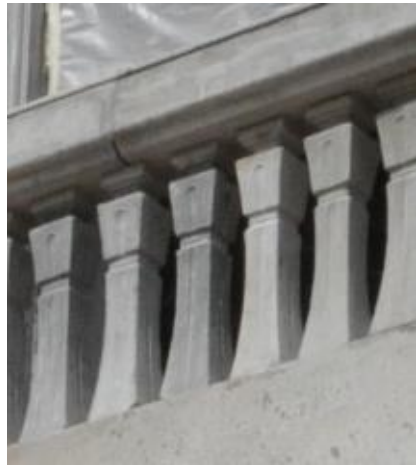

Figure 28: The 'keris' form incised on the balcony's railings and balustrade elements. Sources: Kumpulan Senireka Sdn. Bhd, 2017

\section{Balustrade, Railings and Fencing}

Balustrades in Malay traditional architecture range from timber forms such as in figure 27. Due to the difficulties in designing balustrades that reflect national identity, the decision was to use the local yet universal symbol of the 'keris' to evoke Malay identity. The 'keris' form is incised on the balcony's railing elements as per figure 28 . 
PLANNING MALAYSIA

Journal of the Malaysia Institute of Planners (2018)

\section{CONCLUSION}

There is still exist a gap in the formulation of a language in the context of the urban development of cities which can be derived from the traditions of the past including the Malay palatial architecture, and to learn from its principles and vocabulary. The distillations of such Malay architectural language are critically needed as these would not only reflect the regional identity and present a symbolic expression of urban buildings but a path towards sustainability. Without such forms, there is a tendency to copy and evoke Western or Arab elements in public buildings because lack of local grammar of masonry buildings. Some may think that the traditional Malay architecture arec rooted the past and such forms may not be relevant or fashionable enough to the modern world. Hence, there are examples related to the urban language which relate to the sustainability of the city which requires an in-depth study of tectonic elements that can be derived from the intrinsic values and forms of traditional architecture in urban contexts. Secondly, efforts of deriving national identity at national and international levels should be studied and understood. The issues for Malaysian architects, clients and government bodies are the application of Malay architecture values and design in contemporary administrative buildings. More analysis need to be done on masonry elements of traditional palaces such as to pave the path forward. The resolution of Malay architecture language is crucial for the stability, identity, socio-culture development and maturity of the nation.

\section{ACKNOWLEDGEMENT}

The authors would like to acknowledge the Transdisciplinary Research Fund (TRGS16-03-001-0001) from Ministry of Higher Education, Kumpulan Senireka Sdn. Bhd. and Istana Negara for the support of this research.

\section{REFERENCES}

E. Hosseini, G. M. (2012, April). Design values in traditional architecture: Malay house. 6th International Seminar on Vernacular Settlements, Contemporary Vernaculars: Places, Processes and Manifestations. April 19-21, 2012, Famagusta, North Cyprus.

Kamarul Syahril Kamal, Lilawati Abdul Wahab, \& Asmalia Che Ahmad (2004, November). Climatic design of the traditional Malay house to meet the requirements of modern living. The 38th International Conference of Architectural Science Association ANZAScA "Contexts of architecture". November 10-12, 2004, Launceston, Tasmania, Australia.

King, R. (2007). Re-writing the city: Putrajaya as representation. Journal of Urban Design, 12(1), 117-138.

Moser, S. (2012). Circulating visions of ' High Islam': The adoption of fantasy middle eastern architecture in constructing Malaysian national identity. Urban Studies 49(13), 2913-2935. 
Tengku Anis Qarihah Raja Abdul Kadir, Puteri Shireen Jahn Kassim \& Nurul Syala Abdul Latip

Identity, Tradition and The City: Dichotomies and Realities of Creating an Urban Language of the Malay Palace

Nasir, A. H. (1997). Warisan senibina Melayu. Bangi: Universiti Kebangsaan Malaysia.

Sherif, M. N. (2015). The National Palace of Malaysia; A symbol of sovereignty and majestic of the Malay Sultanate's. Kuala Lumpur: Maya Maju (M) Sdn. Bhd.

Shireen Jahn Kassim, N. M. (2017). The resilience of tradition. Penang: Areca Books.

Tengku Anis, S. N. (2017, September). Classical hybrid language of malay aristocratic buildings identifying generic and variant forms. International Conference on Universal Design in the Built Environment 2017. September 14, Petaling Jaya, Selangor, Malaysia.

Yuan, L. J. (1997). The Malay house: Rediscovering Malaysia's Indigenous shelter system. Pulau Pinang: Institut Masyarakat. 